\title{
Chapter 2 Fideism and Scepticism in The Kuzari
}

Ancient Hellenistic scepticism was a thoroughly rational school of thought which viewed intellectual questioning as the exclusive pathway for discussing theoretical matters. Its basic definition - skepsis as constant searching ${ }^{1}$ - obligated sceptics to take the path of rational discussion, the only method available to them in debates with their dogmatic rationalist adversaries. In their discussions, the sceptics' only tool was rational philosophical debate. In the transition to cultures where religions of revelation were a formative component, sceptical manifestations had lost the homogenous rational nature that they had possessed in the ancient Hellenistic tradition. Scepticism in such cultures became far more heterogeneous and multifaceted with regard to rationalism. Unlike their predecessors in Hellenistic times, whose discourse was thoroughly rationalistic, thinkers with a tendency to scepticism who were active in later cultures worked within multiple discourses simultaneously, both rationalistic and non-rationalistic. In this context, the concept of fideism played a major role. To generalise, fideism is a theory that maintains that faith is independent of reason. As such, in the fideist approach, intellectual pursuit is considered to be an inappropriate foundation for religious belief. ${ }^{2}$ However, this attitude to rationalism is not uniform. Pure or radical fideism denotes an approach that utterly rejects the need for intellectual inquiry, giving faith an exclusive status in terms of attaining and grounding positive knowledge of any kind, whereas moderate fideism distinguishes and separates fields in which intellectual inquiry is valid and leads to knowledge, and is therefore both legitimate and necessary, from fields in which intellectual inquiry is invalid and fails to lead to knowledge, and is therefore illegitimate and unnecessary. The latter fields are those with significance and relevance to religious belief. ${ }^{3}$

In recent decades, fideism has merited a revival in the study of manifestations of scepticism in European Christian culture in the early modern period. Several scholars, most notably Richard Popkin, have drawn attention to the great versatility of fideism in understanding how sceptical lines of thought were adapted and incorporated into the thought of various thinkers from the end of the fifteenth century and through the sixteenth and seventeenth centuries. ${ }^{4}$ The fideist component was in large part responsible for the transformation of ancient scepticism and its adaptation into a framework of thought for European Christian thinkers in the early mod-

1 Sextus Empiricus, Outlines of Scepticism, 3 (I, 1-3), 4 (I, 7).

2 Richard Amesbury, "Fideism," in The Stanford Encyclopedia of Philosophy, Fall 2017 Edition, ed. Edward N. Zalta, https://plato.stanford.edu/entries/fideism/ (last visited 14.5.2019), 1.

3 See, in this context, Popkin, The History of Scepticism from Savonarola to Bayle, 79, 89-90.

4 Popkin, xxi-xxii, 17-98, 274-302; Terence Penelhum, God and Skepticism: A Study in Skepticism and Fideism (Dordrecht: Reidel, 1983), 31-39; Penelhum, "Skepticism and Fideism," in The Skeptical Tradition, ed. Myles F. Burnyeat (Berkeley: University of California Press, 1983): 287-318. 
ern period. For sceptics in classical antiquity, using the tools of scepticism was meant to undermine the dogmatists' pretensions to assent on certain positions. In terms of the Christian European fideists during the early modern period, they often engaged in a turn to sceptical thought as part of their confrontations with the rationalist dogmatic schools that were prevalent in this period. In this sense, the similarity between the eras is only partial. Hellenistic sceptics did not stray beyond the limits of rational arguments. This was not the case with the early modern fideists. From their perspective, the use of the rationalistic tools of the sceptical approach merely prepared the way for faith. The purpose of the debate with the rationalists was to provide a foundation and backing for these thinkers' appeal to religious belief as a supra-rational outlook.

Compared to the development noted in research into sceptical manifestations in European Christian thought in the modern era, where fideism played a central role, research into sceptical manifestations in Arabic culture (which is at a much more preliminary stage) has yet to recognise the importance of this concept. Patricia Crone made a general remark about the potential inherent in studying the development of scepticism in Arabic culture in the context of fideism; ${ }^{5}$ Paul L. Heck, in his book on scepticism in classical Islam, mentioned the concept only a handful of times, and on the few occasions that he brought it up, he attempted to absolve the thinkers under discussion of the suspicion of it. ${ }^{6}$ In this study, I wish to meet Crone's challenge and, using Halevi's thought as a case study, to demonstrate the value of an analysis of sceptical manifestations in Arabic culture in the context of the discussion of fideism.

When it comes to religious belief, fideism's approach is, inter alia, a reaction to the dogmatic rationalist approach. While the latter's approach is to insert intellectual inquiry into the field, the fideist approach works in the opposite direction: extricating religious beliefs from the tentacles of intellectual inquiry. Fideism seeks to re-establish the superior, independent status of religious belief, liberated from the intellectual quest. The classical Islamic period was the first period of time during which dogmatic rationalism made a lasting impact on Judaism (unlike sporadic precedents, such as Philo of Alexandria in the first century CE). This development was one of the most important revolutions in the history of Judaism: its dogmatisation, which was simultaneously also a theologisation. ${ }^{7}$ This revolution was a direct

5 Crone, Islam, the Ancient Near East and Varieties of Godlessness, 126.

6 Heck, Skepticism in Classical Islam, 28, 29, 52, 100. Fideism gained its pejorative connotation when the Catholic Church labelled it heresy associated with Protestantism: see Popkin, The History of Scepticism from Savonarola to Bayle, xxii.

7 Menachem Kellner, Dogma in Medieval Jewish Thought: From Maimonides to Abravanel (Oxford: Oxford University Press, 1986), 1-9 (in particular, 4: "Judaism, for the rabbis of the Talmud, was not a series of propositions which could be either affirmed or denied. Rabbinic Judaism does not demand belief that certain propositions are true or false; it does demand belief in [emunah] or trust 
outcome of the fact that from the ninth century onwards, Jewish thinkers within the general Arabic culture encountered with dogmatic rationalist trends. First was the encounter with Syriac- and Arab-speaking Christian theologians. ${ }^{8}$ Next came the encounter with the scholastic dogmatic rationalist trends developed within the $\mathrm{Mu}^{\text {'ta- }}$ zilite and (to a lesser extent) Ash'arite schools of the Muslim kalām (Islamic scholastic theology), as well as with the dogmatic rationalism of falsafah, an Arab philosophy that created an original synthesis between Aristotelian and Neoplatonic concepts.

In The Kuzari, Halevi presented the first significant and enduring reaction to the revolutionary step by which Judaism was defined in the spirit of dogmatic rationalism. The fact that this response was fideist in nature made Halevi the initiator of the fideist tendency in Jewish thought. ${ }^{9}$ Halevi's fideism is not based on radical anti-rationalism, which attached no value at all to the human intellect, but rather on moderate fideism, which sought only to place limits on it. The catch in Halevi's fideist approach lay in the fact that important aspects of religious belief fall outside the limits of the human intellect. Halevi's moderate fideism was based on a series of hierarchical distinctions whose order is inverse to the values of his era's dogmatic rationalism. In each of the distinctions, the rationalist aspect receiving emphasis and preference in dogmatic systems loses this preference and becomes secondary to its arationalistic aspect. Because the manifestations of scepticism in The Kuzari are woven into the fabric of the work's far-reaching fideist approach, it would be appropriate to precede the detailed presentation of these manifestations with a brief general discussion about the hierarchical distinctions specific to The Kuzari.

One such hierarchical distinction is between "the rational political commandments” (al-šarā'i ' al- 'aqliyyah wa-l-siyāsiyyah), commandments whose utilitarian aspects the human mind can comprehend, and "the divine commandments known through revelation alone" (al-šarā'i ' al-ilāhiyyah al-sam'iyyah), those whose purpose the human intellect cannot discern. Unlike the former, the latter are unique to the religion of Israel and are the means of realising the special relationship between the people of Israel and God. Halevi reopened the discussion of the distinction between the revealed-rational ('aqliyyah) and the revealed alone (sam'iyyah) commandments, which originated in the kalām literature of the Mu'tazilite school of

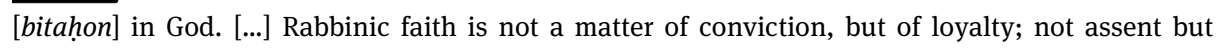
consent”).

8 Stroumsa, "Saadya and Jewish Kalam," 75-78.

9 For example, Judah Halevi is the source of the sceptical-fideist argument found in the sermons of Judah Moscato (1532/33-90), who also wrote a lengthy commentary on The Kuzari. See Giuseppe Veltri, "Principles of Jewish Skeptical Thought: The Case of Judah Moscato and Simone Luzzatto," in Rabbi Judah Moscato and the Jewish Intellectual World of Mantua in the 16th-17th Centuries, ed. Giuseppe Veltri and Gianfranco Miletto (Leiden and Boston: Brill, 2012), 20. 
thought. ${ }^{10}$ The identification of the revealed alone (sam iyyah) commandments with the divine (ilähiyyah) commandments is evidence of a turning point in the spirit of the fideist approach that Halevi was attempting to establish. The dogmatic rational theology, whose prominent spokesmen in Judeo-Arabic culture were Sa'adia Gaon and Maimonides, stressed the importance of rationalisation in the discussion of the purpose of the commandments. This emphasis was manifested not only in the greater significance that these thinkers attributed to the rational commandments, but also in their efforts to provide rational explanations even for the revealed alone commandments. ${ }^{11}$ Halevi, by contrast, stressed the importance of the category of the revealed alone non-rationalistic commandments and placed it above that of the revealed-rational commandments. ${ }^{12}$

Another hierarchical distinction Halevi took from dogmatic rationalist Arab literature is that between the adoption of practices and opinions through reliance or imitation (taqli d) and the establishment of practices and opinions through rational intellectual considerations ( $q i y \bar{a} s$, iğtihād, $r a^{\prime} y$ ). Just as Halevi inverted the usual hierarchy in Judeo-Arabic dogmatic rationalism regarding the relationship between revealed-rational and revealed alone commandments in the written Torah, he also inverted the accepted hierarchy in this dogmatism regarding the application of imitation and rational considerations in the oral law and core beliefs. Halevi speaks in favour of imitation and the preference for the "intuitive natural believer" (al-sad $\underline{a} \bar{g}$ $\left.a l-m a t b \bar{u}^{\prime}\right)$ in whom the core beliefs are embedded and who is therefore exempt

10 Richard M. Frank, "Several Fundamental Assumptions of the Bașra School of the Mu'tazila," Studia Islamica 33 (1971): 14-15.

11 See Isaac Heinemann, The Reasons for the Commandments in Jewish Thought: From the Bible to the Renaissance, trans. Leonard Levin (Brighton, MA: Academic Studies Press, 2008), chapters 6, 8, and 11.

12 The Kuzari II, 48; III, 7. See the additional discussions in I, 79, 97-99; II, 56; III, 23, 53. There are two print editions of the original Judeo-Arabic text of The Kuzari: the first was edited by Hartwig Hirschfeld (Das Buch al-Chazari des Abu-L-Hasan Jehuda Hallewi: Im Arabischen Urtext sowie in der Hebräischen Übersetzung des Jehuda ibn Tibbon [Leipzig: O. Schulze, 1887]) and the second, improved edition is that of David H. Baneth and Haggai Ben-Shammai (Kitāb al-radd wa-l-dalìl fi aldìn al-d̆alī - Al-Kitāb al-hazarī [Jerusalem: Magnes, 1977]). A few years ago, an Arabic-Arabic edition based on Baneth and Ben-Shammai's Judeo-Arabic edition was published by Nabih Bashir: see Al-Kitāb al-Hazarī - Kitāb al-radd wal-dalì fí al-dīn al-dalìl, transliterated into Arabic and edited by Nabih Bashir (Beirut and Freiberg am Neckar: Manšūrāt al-ğamal, 2012). Each reference to The Kuzari includes the part (indicated in Roman numerals) and the section in this part (indicated in Arabic numerals). In longer sections, I will indicate the location in the Hirschfeld edition (pages and lines, which were also incorporated into the Baneth and Ben-Shammai edition) and the corresponding pages in the Bashir edition. The English translations from The Kuzari, with modifications, are taken from the translation by Barry S. Kogan and Lawrence V. Berman scheduled to be published in the Yale Judaica Series. 
from the rational intellectual effort needed to acquire them. ${ }^{13}$ These statements were a clear challenge to the customary approach in the dogmatic rationalism of this era. This approach, whose leading articulations appeared in the Ash'arite school of kalām, viewed tradition as the starting point of the naïve believer from which he must liberate himself in the course of his spiritual/intellectual process of growth when he reacquires the core beliefs by means of applying his own rational intellectual considerations. ${ }^{14}$

Halevi presents a third distinction: one between human wisdom (al-hikmah alinsāniyyah) and divine wisdom (al-hikmah al-ilāhiyyah). Human wisdom includes the fields of knowledge that may be definitively ascertained through intellectual inquiry. In the dialogue in The Kuzari, the Jewish rabbi notes that the sciences of mathematics and logic belong to this field of knowledge as in these sciences, intellectual inquiry leads to universally valid results. As for the reduction of the fields in which the human intellect is applicable in the distinction between human wisdom and divine wisdom, this is the distinction par excellence by which Halevi places his fideism on a collision course with the dominant dogmatic philosophy of his time: falsafah. Halevi locates the matters under discussion in the two uppermost fields of falsafah - much of physics (al-țabī'ah) and all of metaphysics (mā ba'd al-țabì'ah) in the realm of divine wisdom in which "the light of prophecy," not intellectual inquiry, is relevant and determinant. ${ }^{15}$

A fourth hierarchical distinction Halevi makes is between the name elohim the name representing the general attributes of the divine regarding the connections between the divine and the world; that is, properties that may be comprehended through intellectual inquiry - and the Tetragrammaton, the name of the divine whose attributes are connected to the special relationship between God and His chosen, above all the chosen group of the people of Israel. Here, too, Halevi conjures up an inversion in the preferences established in Judeo-Arabic rationalist literature: the unique attributes of God in relation to His chosen are primary and superior to the general and universal. ${ }^{16}$ Epistemologically, the fideist catch in this inversion lies in the fact that as far as Halevi is concerned, the verification of the unique

13 I, 65; III, 35-37, 47 (196, ll. 1-3 = Bashir, 398), 73 (220, ll. 15-18 = Bashir, 428); IV: 3 (230, ll. 1-4 = Bashir, 436; 232, 1l. 21-24 = Bashir, 441), 17 (260, 1l. 25-28 = Bashir, 474); V, 16, 21 (356, 1l. 1-4 = Bashir, 564). See the discussion in Diana Lobel, Between Mysticism and Philosophy: Sufi Language and Religious Experience in Judah Halevi's Kuzari (Albany, NY: SUNY Press, 2000), 75-78.

14 Richard M. Frank, "Knowledge and Taqlid: The Foundations of Religious Belief in Classical Ash'arism," Journal of the American Oriental Society 109, no. 1 (1989): 48-50.

15 IV, 13; V, 14. See the lengthy discussion in the next chapter.

16 IV, 1-3, in comparison with Bahya ibn Paqudah, Kitāb al-hidāyah ilā farā'ị̣ al-qulūb, ed. and trans. Yosef Qāfih (Jerusalem: 'Aqiva Yosef, 1973), 80-82 (= The Book of Direction to the Duties of the Heart, trans. Menahem Mansoor [London: Routledge and Kegan Paul, 1973], 138-41); Abraham ibn Ezra, Perushšei ha-Torah le-Rabbenu Avraham Ibn Ezra, ed. Asher Weiser (Jerusalem: Mossad haRav Kook, 1977), vol. 2, Šemot, 20, 2-3 (Long Commentary; see the discussion in the next chapter). 
properties of the divine has nothing to do with intellectual realisation. Rather, it is connected to a sense experience ('iyān, mušāhadah) in the case of the mass of people belonging to the chosen group, ${ }^{17}$ whereas in the case of the elites of the chosen group, such as the prophets and the saints (awliy $\bar{a}^{\prime}$ ), the recognition is also non-intellectual: a mystical, super-sensory experience. This recognition is described in terms borrowed from Șūfĩ vocabulary, such as "spiritual insight" (bașīrah), "vision" (mušāhadah), ${ }^{18}$ "the spiritual eye" or "the internal eye" (al-'ayn al-bātinah, al-'ayn al-ruḥāniyyah), ${ }^{19}$ and "mystical taste/experience" (dawq) ${ }^{20}$ The hierarchical distinction between the divine attributes of the name elohim and those of the Tetragrammaton is incorporated into Halevi's most significant fideist move in The Kuzari, which is found in a large portion of part IV, starting at its beginning. In this part of the book, Halevi's line of argument points to the lack of precision and clarity in the perception of God that relies on "the ways of seeking proof through inference" (turuq al-istidlāl). Any debate relying on the production of rational evidence, even at its best, such as in philosophical deliberations, is incapable of achieving more than a sketch of a distant, passive figure of God (the one manifested by the name elohim). The way to achieve a clearer and deeper concept of God and His relationship with the world, one that describes His active side in relation to His creatures and His special connection to a chosen group of mankind (the one manifested by the Tetragrammaton), is only possible though non-rational, non-intellectual means. The height and conclusion of this central fideist move in The Kuzari is formulated by means of a distinction between the comprehension of God as "the God of Abraham" and the comprehension of Him as "the God of Aristotle." "The God of Abraham" is attained through mystical means. This comprehension arouses feelings of longing $(\check{s} a w q)$ and an experience of annihilation in His love (al-istihlāk fi hubbihi) in the one who experiences it. Faced with this total comprehension, "the God of Aristotle" - that is, comprehension attained through intellectual inquiry - is but a pale shadow, as it is incapable of motivating the believer to accept a profound commitment in his relationship with God. ${ }^{21}$

Alongside the hierarchical distinctions described above, Halevi's fideist approach in The Kuzari is noted for its prominent ambivalent character. Together with the many clear expressions of the inadequacy and inappropriateness of intellectual

17 I, 11-25, 83 (36, 1. 22 = Bashir, 198), 109 (58, ll. 21; 60, ll. 7-8 = Bashir, 223-24); II, 48 (108, ll. 1315 = Bashir, 290), 54 (114, ll. 8-11 = Bashir, 296); V, 14 (330, ll. 9-10 = Bashir, 540). See the lengthy discussion in the next chapter.

18 III, 1 (140, ll. 8-9 = Bashir, 330), 65 (214, 1. 26 = Bashir, 423); IV, 3 (228, 1l. 11-12; 230, ll. 1-2 = Bashir, 435, 436), 15 (258, ll. 17-19 = Bashir, 471-72), 16 (260, 1. 7 = Bashir, 473).

19 IV, 3 (238, 1. 28-240, 1. 1; 240, 1. 8-9; 242, 1l. 18-25 = Bashir, 448, 451-52).

20 IV, 16, 17 (260, 1l. 7, 14-15, 20 = Bashir, 473-74).

21 IV, 16 (260, 1l. 5-8 = Bashir, 473) See the extensive discussion in Lobel, Between Mysticism and Philosophy, 89-111. 
inquiry with regard to the essential matters of belief and religion in the work, the author devotes much space to discussions that involve many rationalistic explanations of these very matters. Below, I provide several examples of this ambivalent character that accompanies Halevi's fideist approach in The Kuzari.

In various places throughout the book, starting from its very first part, Halevi insists that the commandments categorised as "divine" (al-šarā'i al-ilāhiyyah), the most prominent of which are the commandments associated with the Temple rituals, cannot be rationally explained. However, despite this clear-cut declaration, in section 25 of the second part of the work, where the Khazar king is addressing his rabbi and complaining that the sacrifices are a matter that is "difficult for the intellects to accept” (yašuqqu 'alā al-'uqūl qubūluhu), in section 26, the rabbi responds by presenting a long explanation in which he attempts to provide explanations for the Temple ritual commandments that are in the spirit of the rationalist approach. He concludes his long discussion of the matter with an apology, according to which the explanation he offered fails to plumb the depths of the matter being discussed, but adds that it is unnecessary in any case from the perspective of the non-sophisticated firm believer. The utility of such explanations is reserved for those who have diverted from this level towards intellectual inquiry. ${ }^{22}$ Similarly, in a later section of the second part of the work, the Khazar king addresses the rabbi again, asking for a rational explanation of the Pentateuch's laws of sara' $a t,{ }^{23}$ included among the "divine commandments." In reply, the rabbi begins with a fundamental fideist declaration about the impossibility of providing such explanations. He reminds the Khazar king that he has already explained to him that "there is no correspondence between our intellects and the divine order" (lā munāsabah bayna 'uqūlina wa-l-amr al-ilāhì). Afterwards, he apologises and begins to provide the Khazar king with rational explanations for these laws. ${ }^{24}$

The ambivalence in Halevi's fideism is perhaps most prominently displayed in the long third section of part IV of the work. At the beginning, the author puts decisive words into the rabbi's mouth about the errors to which "seeking proof through

22 II, 26 (98, 11. 22-28 = Bashir, 277): "I do not categorically assert, nor do I say with certainty - God forbid! - that the purpose of this service is simply this order of which I speak. On the contrary, it is something more mysterious and exalted, inasmuch as it is truly a Law from God. One who accepts it completely without engaging in intellectual speculation about it and without making himself the judge of it is better than someone who engages in intellectual speculation and investigates. However, for someone who slips from that exalted level to that of investigation, the most suitable course is to turn his attention towards some aspect of wisdom concerning it, rather than renounce it altogether because of evil opinions and doubts, which lead to disaster."

23 An unidentified ailment described in Leviticus and commonly translated as "leprosy."

24 II, 60 (118, ll. 16 ff. = Bashir, 303): "I have already told you that there is no correspondence between our intellects and the divine order and we ought not to look for an explanation of great things like these. Nevertheless, after first asking His forgiveness and also absolving myself of the charge that I am claiming categorically that it is all just like this, I will say that [...].” 
inference" (istidlāl) is prone to lead when it is aimed at metaphysical matters. When it comes to these, the rabbi extols the superiority of the knowledge acquired "by prophetic vision and spiritual insight” (bi-l-mušāhadah al-nabawiyyah wa-bi-lbașirah). ${ }^{25}$ However, later in the same section, the rabbi opts for an explanation which builds upon rational inferences (istidlāl) for the phenomenon of prophecy itself. ${ }^{26}$

In section 24 of part IV, the Khazar king addresses the rabbi and asks him to present something about "the remnants of the natural sciences" (baqāyā al-'ulūm al-tabi 'iyyah) known to the Jews in ancient times and now mostly lost during the various exiles. ${ }^{27}$ In response, the rabbi draws the Khazar king's attention to the short work Sefer Yeșirah (Book of Creation/Formation), attributed to the patriarch Abraham. Subsequently, in section 25, the rabbi presents the Khazar king with an explanation of long passages of that work, relying mostly on the philosophical terminology used in Arabic culture. The spirit of the explanation and certain attitudes embedded in it are congruent with those of the philosophical rationalism common to that era. ${ }^{28}$ When it comes to the words he places in the rabbi's mouth to explain Sefer Yeșirah, Halevi's general tendency is to show that this work, as one of the remnants of the ancient Jewish sciences, proposes a kind of cosmology that is more persuasive than falsafah's cosmology, which relies on the rebutted principle of the emanation of separate intellects. ${ }^{29}$ However, immediately thereafter, in a direct continuation of the Khazar king and the rabbi's dialogue about Sefer Yeșirah, Halevi manages another inversion, this time in the spirit of the fideist approach to the distinction between the sphere of "human wisdom" and the sphere of "divine wisdom" included in it. According to what Halevi attributes to the rabbi at this stage of the discussion (section 27), the cosmology of Sefer Yeșirah, which he has already presented as being superior to that of falsafah, belongs to an early and immature stage

$25 \mathrm{IV}, 3$ (228, 1. $11 \mathrm{ff}$. = Bashir, 435): "Certainly, one can refer to Him by means of prophetic vision and spiritual insight because seeking proof through inference leads one astray. Moreover, both heresy and corrupt doctrines come into being by seeking proof through inference."

26 In the presentation of the rational explanation for prophecy in IV, 4, Judah Halevi used conjugations of the terms istidlāl: bi-țarīq al-istidlāl (236, 1. 5), yastadillu minhā al-'aql (238, 1. 1), istadlalnā bihā (238, 1. 10), and fa-yastadillu minhā al-'aql (238, 1. 19). Warren Zev Harvey has pointed to the evident discrepancy in the argumentation between the middle part of IV, 3, where Halevi presents this explanation (236, 1. 6-240, 1. 13 = Bashir, 444-48), and either the first part or the last part of the same section. The exceptionality of the part that contains the rational explanation of prophecy in IV, 3 has led Harvey to suggest that Judah Halevi added it while revising an earlier draft of this section. See Warren Zev Harvey, “Judah Halevi's Synthetic Theory of Prophecy and a Note on the 'Zohar'” [Hebrew], Jerusalem Studies in Jewish Thought 12 (1996): 141-42.

27 Compare II, 63-68; III, 63; IV, 29-30.

28 See Raphael Jospe, "Early Philosophical Commentaries on the Sefer Yezira: Some Comments," Revue des études juives 149 (1990): 392-402.

29 IV, 25 (280, 1. 4-282, 1. 8 = Bashir, 496-97). Compare V, 14 (330, ll. 4-5 = Bashir, 540). 
in Abraham's spiritual development, from which he distanced himself once divine revelation was granted to him. At the higher stage of his spiritual development, Abraham was instructed to stop engaging "with any doubtful natural science” (kull 'ilm țabì ‘̄ maškūk). ${ }^{30}$ Basing himself on a homiletical interpretation of the Talmudic sages, Halevi backs up this instruction with an anecdote attributed to Plato which contains a fideist message, according to which the path to the divine goes through the prophets and their revealed laws rather than through philosophical inquiry. ${ }^{31}$

In the fifth and last part of The Kuzari, the tension between the dogmatic rationalist and fideist perspectives and the frequent shuttling from one to the other are very obvious. At the beginning of this part, the Khazar king immediately confesses that "since the exalted level of pure belief without investigation is simply beyond me," he cannot help asking to provide him with a dogmatic presentation of his religion. He asks this in the form of "the religion's principles and core beliefs" (al-ușūl $\left.w a-l_{-}{ }^{\prime} a q \bar{a}^{\prime} i d\right)$ in the manner of the masters of kalām. ${ }^{32}$ The rabbi diagnoses the Khazar king's desire for a dogmatic presentation of his religion as being caused by the mentality spread by different dogmatic currents that has infected everyone in present-day culture, except for a happy few. ${ }^{33}$ He assures the Khazar king that he is ready to satisfy his dogmatic need, but then, instead of beginning a discussion in the spirit of the masters of kalām, he chooses to engage in a discussion about the concepts of the masters of falsafah. This discussion reaches its peak in section V, 12, where the rabbi presents a dogmatic formulation of the philosophical doctrine of the soul, a presentation that merely paraphrases several sections of Ibn Sīnā's work on the topic. ${ }^{34}$ Subsequently, in section V, 14, the author veers sharply and excoriates the doctrine of the soul and another doctrine of falsafah (the theory of the separate intellects) in the name of a fideist distinction between "human wisdom" and "divine wisdom." Afterwards, in section V, 15, the Khazar king repeats the request

30 IV, 26-27 (282, 11. 15-28 = Bashir, 498-99).

31 IV, 27 (282, 1. 28-284, 1. 3 = Bashir, 499): "[In this connection,] Plato has reported concerning the prophet who lived at the time of King Marinus that he told the philosopher who prided himself on [his] philosophy [the following] by means of a revelation from God: 'You will not reach Me in this way, but by means of whomever I have appointed as an intermediary between Me and My creatures,' meaning [here], the prophets and the true nomos.” See Pines, "Shī'ite Terms and Conceptions in Judah Halevi's Kuzari," 236-39, for a parallel of this passage in the pseudo-Platonic Kitāb al-nawāmīs. See also the discussion in Lobel, Between Mysticism and Philosophy, 70-71.

$32 \mathrm{~V}, 1$.

33 V, 2 (294, 11. 11-15 = Bashir, 511-12): "But who among us has a steadfast soul that is not misled by the opinions that pass through it, such as those of natural scientists, astrologists, believers in talismans, magicians, materialists, those who devote themselves to philosophy, and others? One arrives at faith only after having come through many ranks of unbelievers. [...] [By contrast, having] faith by nature happens only to unique individuals."

34 See Abū 'Alī ibn Sīnā, Maqālah fi al-nafs, in Samuel Landauer, "Die Psychologie des Ibn Sina," Zeitschrift der Deutschen Morgenländischen Gesellschaft 29 (1875): 335-418. 
he made at the beginning of this part, which has not yet been satisfied, for a presentation of the fundamentals of the religion according to the masters of kaläm. In answering, the rabbi makes use of his fideist distinction regarding the superiority of the intuitive or natural believer ( $a l-s a \underline{a} \bar{a} \breve{g}$, $a l-m a t b \bar{u}$ ) over the believer who acquires his belief through an intellectual inquiry in the manner of the masters of kalām. He concludes by averring that the path of kalām is useless, and perhaps even harmful, from the perspective of those who are not intuitive believers. ${ }^{35}$ Nonetheless, as the discussion continues, he accedes to the Khazar king and lays out a dogmatic presentation of the fundamentals of his religion in the spirit of kalām in section $18 .^{36}$ Later on, in section 19, the Khazar king asks the rabbi to discuss "the question of [divine] predestination and [human] free choice” (mas'alat al-qadar wa-l-ihtiyār), another of the issues of great concern to the masters of kaläm and falsafah. In section 20, the rabbi again acquiesces to the request and offers the king an argument which, in its form and manner of presentation, is close to the argument over the issue in the Ash'arite school of kalām, especially the formulations found in several of al-Gazālì's writings. ${ }^{37}$ The argument concludes with the rabbi's words being summarised in section 21 in the spirit of the fideist preference for the adoption of practices and opinions through faithful reliance or imitation (taqlid) over inferences (istidlāl) when it comes to the fundamentals of belief. ${ }^{38}$

The ambivalence characterising Halevi's fideism, some representative examples of which I have cited above, is a fascinating, albeit perplexing, element of The Kuzari. This ambivalence is a central enigma in understanding the moves Halevi makes as someone rebutting the dominant trends of dogmatic rationalism in the Judeo-Arabic thought of his era. It has enabled some scholars to claim that despite the declarative tone in which the rejection of dogmatic rationalism is made, Halevi never succeeded in severing his own thought from it and remained caught in its

35 V, 16. See the discussion in Lobel, Between Mysticism and Philosophy, 76-77, 173-75.

36 In the presentation of the principles of theology (ușūl) in section V, 18, Judah Halevi draws from a kalām treatise by al-Ghazālī known as the Jerusalem Epistle (al-Risālah al-qudsiyyah). See Martin Schreiner, Gesammelte Schriften: islamische und jüdisch-islamische Studien, ed. Moshe Perlmann (Hildesheim: G. Olms, 1983), 105-9.

37 See Binyamin Abrahamov, "Will and Choice in the Kuzari" [Hebrew], in Alei Asor: Proceedings of the Tenth Conference of the Society for Judeo-Arabic Studies, ed. Daniel J. Lasker and Haggai BenShammai (Beer-Sheva: Ben-Gurion University Press, 2008): 11-19.

38 V, 21 (354, 1. 27-356, 1. 4 = Bashir, 564): “Therefore, you must also relinquish the Karaites' [practice of] citing as a prooftext David's charge, peace be upon him, to his son, And now, my son, Solomon, know the God of your father and serve Him (1 Chron. 28:9), as well as the inference they draw from it that one needs true knowledge of God [first], and [only] then does worshipping Him become obligatory. On the contrary, he urged only faithful reliance upon the tradition of his father and his ancestors with regard to belief in the God of Abraham, the God of Isaac, and the God of Jacob." 
web. ${ }^{39}$ The main source of this ambivalence is, in my opinion, to be found in the fact that essentially, there is no connection between the experiential mystical "language” expressing the experience of God's revelations to His prophets and chosen that is, the language at which Halevi's fideism mainly aims - and the discursive language characterising rational thought. The presence and the proximity of the divine, experienced by the prophets and saints ( $a w l i y \bar{a}^{\prime}$ ), cannot be expressed or explained by means of rational discursive language. It is also impossible to clarify such an experience to someone who has never been granted it. Halevi exemplifies this teaching in a parable which stresses the fundamental difference between an expert in prosody and a natural poet. Compared to the expert, the poet might be ignorant of the science of prosody and unable to teach it to others. The poet's ability to compose a poem is based on his innate capacity, one that enables him to "taste" the required meters, lacking theoretical knowledge about them. Thus, the skills of the prosody expert and that of the poet are completely different from each other: one is theoretical and rational, the other is non-rational and impalpable. While the first relies on his theoretical knowledge, spelt out in discursive language, the second relies on his innate capacity for mystical perception $(\underline{d} a w q)^{40}$ and communicates with others who share the same capacity in an intuitive manner. Furthermore, for the poet, the expert's theoretical knowledge is superfluous. The same holds for the naturally inclined (al-maț $\left.b \bar{u}^{\prime}\right)$ believer both individually and collectively, those people who are naturally inclined to live by the Law (al-qawm al-mațbū'ūn li-l-tašarru'). ${ }^{41}$

39 This view is expressed in a straightforward and impressive manner by Herbert Davidson: see Herbert A. Davidson, “The Active Intellect in the Cuzari and Halevi's Theory of Causality," Revue des études juives 131 (1972): 381. See also Howard Kreisel, "Judah Halevi’s Kuzari: Between the God of Abraham and the God of Aristotle," in Joodse filosofie tussen rede en traditie, ed. Reiner Munk and F. J. Hoogewould (Kampen: Kok, 1993): 24-34.

40 See Denis Gril, "Dhawq," in Encyclopaedia of Islam, THREE, ed. Kate Fleet, Gudrun Krämer, Denis Matringe, John Nawas, and Everett Rowson (consulted online on 06 February 2020. http:// dx.doi.org/10.1163/1573-3912_ei3_COM_26001), art. 5 (Ṣūfism).

$41 \mathrm{~V}, 16$ (330, 1. 22-332, 1. 3 = Bashir, 541-42): "Like those we see in connection with people who read treatises on prosody and pay close attention to their poetic meter. We hear [lots of] bluster and frightful speeches about a [kind of] knowledge that comes easily to the person who is naturally inclined to it (al-mațbü), who 'tastes' (yadūqu) the meter of the verses, and for whom crawling along little by little just won't do. Moreover, the ultimate goal of the former is to become like the latter, who seems to be ignorant of prosody because he cannot teach it, while those others can teach it. But, surely, this naturally inclined person can teach another naturally inclined person (al-mațbü yu'allimu mațbü a ăhar) with the slightest hint. And it is the same with the people who are naturally inclined to living by the Law (al-qawm al-mațbū'ūn li-l-tašarru') and drawing close to God, exalted be He. Sparks are kindled within their souls by the words of outstanding people and [their words] become lights for them within their hearts. But the person who is not naturally inclined (wa-gayr al$m a t ̦ b \bar{u}$ ) is the very one who needs the science of theological disputation, although sometimes it doesn't benefit him. On the contrary, it frequently harms him." See the discussion in Lobel, Between Mysticism and Philosophy, 175-76. 
From this parable and its moral, we learn that there is an epistemological chasm between the fideist basing his belief on experiences of presence and the proximity of the divine and the dogmatic rationalist founding his belief on verifiable intellectual principles. This fundamental difference (al-farq) between the "God of Abraham" and the "God of Aristotle," which Halevi highlights in distinguishing between the divine name of the Tetragrammaton and the divine name elohim, cannot be bridged. ${ }^{42}$ However, this consistent conclusion, derived from the fideist worldview Halevi formulates in Șūfĩ experiential-mystical terms, which he scatters in parts of The Kuzari, is a decree with which he himself cannot comply. The ambivalence in The Kuzari is a direct outcome of what Halevi viewed as the unavoidable necessity of maintaining a channel of discourse with his dogmatic rationalist colleagues. This necessity led him to give The Kuzari the most discursive literary format possible: that of a dialogue. In turn, the discursive dialogue format is what exposes this ambivalence and makes it so very explicit. As The Kuzari and its format make clear, Halevi was unwilling to abandon the possibility of a dialogue with the dogmatic rationalists, to whom most of his close associates and the Andalusian Jewish intellectuals - his immediate audience of readers - belonged. He therefore opted to enter the rationalist arena of debate and to argue with his colleagues and rivals in their own discursive language. ${ }^{43}$ Moreover, the use of claims that are typical of sceptical philosophy is part of this way of confronting them. At the same time, Halevi had another tool by which he could give proper expression to his innermost perceptions. His poetical genius allowed him to express his experience of proximity to God and His presence in a language suited to that experience; namely, a lofty language moulded in poetic forms. ${ }^{44}$

42 IV, 16 (260, 11. 5-7 = Bashir, 473): "The difference (al-farq) between Elohim and YHVH has become clear to me, and I have also understood the difference between the God of Abraham and the God of Aristotle. One longs for $Y H V H$, exalted be He, by tasting and witnessing for oneself (šawqan dawqan wa-mušăhadatan), while one inclines towards Elohim by reasoning (qiyāsan)."

43 As part of this discourse, Halevi sometimes adopts the dialectic ad hominem (Arb. ilzām) method of argumentation; i.e., refuting the opponent's position by adopting his underlying assumptions for the sake of the debate. This, for example, is the method by which Halevi argues against the falsafah theory of separate intellects in IV, 25 (280, 1. 22-282, 1. 11 = Bashir, 497-98). As noted above, ad hominem argumentation is typical of ancient scepticism. For further discussion of Halevi's use of this device, see chapter 4 below.

44 See, in particular, the translations and commentary in Judah Halevi, Ninety-Two Poems and Hymns of Yehuda Halevi, orig. ed. Franz Rosenzweig, trans. Thomas Kovach, Eva Jospe, and Gilya Gerda-Schmidt, ed. Richard A. Cohen (Albany, NY: SUNY Press, 2000): 12-13 (4. "At Night"), 18-19 (7. “All My Bones"), 24-25 (10. "The Lovers"), 38-39 (15. "Your God"), 52-57 (18. "The Remote and Near One”), 70-73 (23. “Holy”), and 76-79 (24. “The Helper”). See also Isaac Heinemann, “The Philosopher-Poet: Commentary on a Selection of Judah Halevi's Poems" [Hebrew], in Rabbi Judah Halevi - A Collection of Studies and Appraisals, ed. Israel Zemora (Tel-Aviv: Mahbarot le-Safrut, 1950), 176-91; Aaron Komem, "Between Poetry and Prophecy: Studies in Judah Halevi's Poems" [Hebrew], Molad, n.s., 11-12 (1969): 676-97; Raymond P. Scheindlin, The Song of the Distant 
Religious poetry was the most appropriate medium for Halevi to express himself: in this genre, he was liberated from the shackles of discursive discourse, free of the need to speak in a way that would be intelligible to his learned dogmatic rationalist colleagues or to communicate with them using their concepts. Halevi was, first and foremost, a poet. ${ }^{45} \mathrm{He}$ composed his poetry in Hebrew, the only language he acknowledged as the divine tongue. ${ }^{46}$ Halevi's Hebrew religious poetry was the tool he used to give free rein to his thought without compromising the full depth of his faith. An integrative examination of his work, one that encompasses both the discursive thought in The Kuzari and his poetry, engenders an understanding that Halevi's religious mentality is inclined to the non-intellectual, mystical, numinous feeling of awe of the divine and proximity to it. ${ }^{47}$ Such an integrative perspective, which lies beyond the scope of this study, ${ }^{48}$ would make it clear that Halevi was not held captive by concepts of rational thought, as scholars who have only considered his theoretical discursive thought have claimed..$^{49}$ A comparison between the discursive thought in The Kuzari and the non-discursive thought of Halevi's religious poetry would provide us with a different perspective, one that would show that Halevi aimed to elevate himself to heights of mystical proximity to God. From these heights, he tried, as it were, to let down a ladder to his colleagues left "down there" in the realm in which they are still tied to rational discourse. ${ }^{50}$ The lower and middle rungs of that ladder are the ones manifested in The Kuzari. The lower rungs are the

Dove: Judah Halevi's Pilgrimage (Oxford: Oxford University Press, 2008), 70-93; Menachem Lorberbaum, Dazzled by Beauty: Theology as Poetics in Hispanic Jewish Culture [Hebrew] (Jerusalem: BenZvi Institute, 2011), 176-200.

45 Writing poetry was a life-long occupation for Halevi, while theoretical writing occupied him only towards the end of his life, at the time when he compiled The Kuzari.

46 II, 66-68. See Ilan Zim, “The 'Divine Order' in The Kuzari - Its Conceptual Meaning and Understanding” [Hebrew] (MA diss., Tel-Aviv University, 1989), 181-82.

47 For the theoretical background, see Rudolf Otto, The Idea of the Holy: An Inquiry into the NonRational Factor in the Idea of the Divine and Its Relation to the Rational, trans. John W. Harvey (London: Oxford University Press, 1923).

48 An integrative discussion of Halevi's work will be presented in a forthcoming study of mine devoted to Bahya ibn Paqudah and Judah Halevi as radical thinkers (however, the treatment of this subject there is different from the one hinted at here).

49 See, in this context, Lorberbaum, Dazzled by Beauty, 188-89.

50 For the symbol of the ladder (Heb. sullam) as a symbol of spiritual/mystical ascension to God in Judah Halevi's poetry, see Rosenzweig, Ninety-Two Poems and Hymns of Yehuda Halevi, 38 ("And arise at midnight / to step into the footsteps of the great ones / Who, with a plethora of psalms on their lips / with thoughtful steadfast feeling / Spent their day fasting / and their night praying / God is a shaft in their heart / and they the planets who encircle His throne -/ May their way ascend powerfully / to Him, Your God [darkam sullam la'alot 'ad Adonai Elohekha]"). On the motif of the "ladder of ascension" in the philosophically inclined literature of Halevi's era, see Alexander Altmann, “'The Ladder of Ascension," in Studies in Religious Philosophy and Mysticism (Ithaca, NY: Cornell University Press, 1969), 41-72. 
stages of conversation in the dialogue where the rabbi responds to the king's requests and explains his positions to him in the spirit of the rationalist worldview. The fideist side of The Kuzari, the one in which Halevi shifts the debate's centre of gravity from rationalist explanations to critical assertions levelled at the limits and the second-tier status of intellectual inquiry when it comes to non-intellectual cognition, constitutes the middle rungs of the ladder. The upper rungs - the domain of the proximity to the divine - are to be found outside the scope of inquiry of The Kuzari $^{51}$ and belong to the non-discursive mystical experience that Halevi expressed in his religious poetry. The ladder is a metaphor for the gradual effort Halevi makes to help his colleagues - the members of his own circle - to escape their dogmatic entrenchment in the field of intellectual inquiry and redirect them towards the mystical non-intellectual proximity to the divine and the people who exemplify this proximity. ${ }^{52}$

From such a comprehensive, integrative point of view, the ideological moves into which Halevi weaves sceptical motifs, which I will discuss in the next part of this book, are connected to a transition from the lower to the middle rungs of the ladder of cognition. Halevi finds sceptical thought, as a rational alternative to dogmatic thought, to be suited to a critical engagement with his colleagues' dogmatic rationalism. As a fideist, Halevi moves from the realm of rationalist debate to the realm of arational belief, with the centre mass of his worldview being located in the realm of belief. In this context, the use of sceptical arguments fulfils an intermediate

51 See, in this context, Zim, “The 'Divine Order' in The Kuzari," 270, 286-90.

52 Consider the following description in I, 103 (54, 1. 28-56, 1. 7 = Bashir, 219-20): "The children of Jacob came on the scene as the choicest and best part [of their father]. They differ from the [other] children of Adam by virtue of a special divine distinctiveness, which made them as though they were a different species and a different, even angelic, substance. All of them sought the level of prophecy, and most of them did attain it. Those who did not attain it nevertheless came close to it by means of actions that are pleasing, and sanctification, purification, and meeting the prophets. Know that a spiritual transformation comes over someone who meets a prophet at the time that he meets him and hears his divine words. He separates himself from his kind through the purity of his soul, its longing for those [prophetic] levels, and its adherence to humility and ritual purity." The second part of this description emphasises that those who do not attain the level of the prophets and who do not receive divine revelation can still be lifted up and experience a spiritual transformation by associating with the prophets and prophet-like people. The Șūfì background of this part is evident. Compare, for example, the following description by al-Ġazālì: "This is a state which one following the way leading to it will verify by fruitional experience. But one to whom such experience is not granted can acquire certain knowledge of that state through experience of others and hearsay, if he frequents the company of them [i.e., the prophets and the saints - E.K.] so as to have a sure understanding of that from observing the circumstances accompanying their ecstatic states. Whoever associates with them will derive this faith from them, for they are the men whose associate is never wretched.” Abū Ḥāmid al-Ghazālī, Freedom and Fulfillment: An Annotated Translation of al-Ghazālī's al-Munqidh min al-ḍalāl and Other Relevant Works of al-Ghazali, ed. and trans. Richard J. McCarthy (Boston: Twayne, 1980), 82, sec. 98. 
function: the author needs them because he is debating in the rationalist realm, and, at the same time, their use is meant to strengthen and more firmly establish the arationalist, believing side of his worldview. 
